\title{
The Six-Minutes Walking Test (6MWT) in healthy Turkish children and its comparative review
}

\author{
Gulsah SAHIN ${ }^{1}$, Nurdan YAYKIN ${ }^{2}$, Aysegul AKSOY³, Kubra GULTEKIN², \\ Ozan CANPOLAT ${ }^{2}$, Serkan ISIK ${ }^{2}$, Hasim KATRA ${ }^{1}$, Baris KARAKOYUN ${ }^{2}$, \\ Nevin KAYA ${ }^{2}$, Omur KOCAK ${ }^{2}$, Omer DURUKAN ${ }^{2}$, Asli SAHIN", \\ Ozhan BAVLI ${ }^{1}$
}

${ }^{1}$ School of Physical Education and Sport, Çanakkale Onsekiz Mart University, Çanakkale, Turkey.

${ }^{2}$ The Institute of Health Sciences, Çanakkale Onsekiz Mart University, Çanakkale, Turkey.

${ }^{3}$ Faculty of Sports Sciences Gedik University, Istanbul, Turkey.

${ }^{4}$ Sertificated First Aid Person, Swimming Coach, Çanakkale, Turkey.

Address correspondence to Gulsah Sahin, nazgulsah@hotmail.com.

\begin{abstract}
Having data about its own subjective condition is important for each country. The aim of this study was to establish the values for six-minutes walking test (6MWT) among healthy children. The study population included 732 children (342 girls and 390 boys) aged 7-14 from 3 different regions in the city center. Their height and weight were measured and a sixminutes walking test was performed to the children. Mann-Whitney $U$ test for gender and walking distance; Pearson correlation test for the relationship between height, weight and age; Kruskal-Wallis analysis methods for walking distance of the age groups were used. The six-minutes walking (6MWT) distance of the children ages 7-14 was $684.20 \pm 109.31 \mathrm{~m}$ in total. There was significantly positive relation in medium level between children's age and the 6MWT distance. There was a significantly positive relation in medium level between children's height and the 6-MWT distance. There was also a significantly positive relation in low level between children's weight and the 6-MWT distance. A statistically significant difference between the 6-MWT distance according to children's gender was observed. Finally there was a significant difference between 6-MW distance according to the children's age groups.
\end{abstract}

Keywords: Six- Minutes Walking Test, children, physical performance.

\section{INTRODUCTION}

Many tests have been used for measuring children's physical activity level, exercise capacity and their functional capacity. The six-minutes walking test (6 MWT) is a method to provide information about daily physical performance. It is also performed for evaluating the aerobic capacity (endurance) and ability of long-distance walking which gives an accurate measurement of physical capacity of individuals with respiratory diseases. The capacity to perform daily activities is also an important component which reflects the quality of life.

The 6 MWT, which the standarts were published by the American Thoracic Society, is widely used not only for adults but also for predicting physical health which is increasingly applied in pediatrics. The $6 \mathrm{MWT}$ has been used in research on performance, disease and treatment process $(3,5,12)$, but it is also reported in researches in which the lack of normal values of healthy children in a pediatric group has prevented the benefits of the clinical trials of the test $(4,7)$. Having data about its own subjective conditions is also important for a country as a source of preliminary information for other studies in the country, and for making comparisons and inferences.

The purpose of this study was to determine the 6 MWT distances of the healthy children.

\section{MATERIAL \& METHODS}

\section{Participants}

Seven hundred thirty-two children have participated to this study. The population was consisted of children from 3 different regions including the city center and 2 different districts located in the west and east of Canakkale. Voluntary and healthy children aged 7-14 who do not suffer from any chronic disease or from any illness which may occur due to exercise were participants of this 
study. "Volunteer informed consent" was obtained from the parents, and the research was approved by Human Research Ethic Board (Date: 02.08.2012; number: 050.99-131).

Throughout the test, a researcher who has a first aid certificated was ready in the test area. No negative impacts have occured during the tests. The puberty of the children has not been taken into account and there has not been any distinction according to the level of their physical activity. Height and weight of the children were and 6-MWT were applied.

\section{Data Collection}

Six-minutes walking test evaluates submaximal functional capacity by measuring the fast walking distance of the children on a flat survey in a sixminutes period. Besides, the realibility and validity of the test were also proved (15). The test was applied in the schools and the sports hall in which the research was going to be performed. A 30-meters walking trial, whose start and finish line had been set, was designed for the participants aged 7-10 while a 50-meters walking trial, whose its start and finish line had been set, was designed for the participants aged 11-14.

The Children were asked to walk as fast as possible within a six-minutes period, the total distance of the participants was measured as in meters, and consequently the measurement/test results has been recorded in the "test track form" which had been prepared by the researchers. The children were told not to run, but walk as fast as they can while performing the test. Before applying the test, the children on the start line were asked whether they were ready or not. After the children confirmed that they were ready, the "start" command was issued by the researcher, and concurrently/at the same time, the six minutes period was started by the researcher, by using a stopwatch. When the six-minutes period was over, the test was ended up by the researcher saying to participant the "Stop" command. At the end of six minutes, the participants were asked to wait at their last step without moving and the total distance was recorded in meters. The test's manner of application had been described to the participants before the test. Before and during the test the children were motivated verbally by saying; "go! go! go!" , "well done!" etc. (1).

\section{Data Analysis}

Analysing the data, Mann-Whitney $U$ test for gender and walking distance; Pearson correlation analysis for the relationship between weight, height and age; Kruskal-Wallis analysis for the walking distance according to the age group or height groups were applied.

\section{RESULTS}

It was found that the total average of the 6MWT distance was $684.20 \pm 109.31 \mathrm{~m}$.

The relationship between the children's ages and 6MWT: As a result of the analysis, a significantly positive relationship in medium level between children's age and 6MWT ( $r=0.42, \mathrm{p}=0.001)$.

The relationship between the children's height and the $6 \mathrm{MWT}$ : As a result of the analysis, there was a positive significant relationship in medium level between children's height and the 6-MWT $(\mathrm{r}=0.42, \mathrm{p}=0.001)$.

The relationship between the children's weight and $6 \mathrm{MWT}$ : As a result of the analysis, there was a significantly positive relationship in low level between children's weight and 6-MWT $(r=0.20$, $\mathrm{p}=0.001$ ).

The comparison of 6-MWT according to gender: As a result of the analysis, there was a significant difference between the 6-MWT distances according to children's gender $(\mathrm{p}=0.003)$.

The comparison 6-MWT according to age groups: As a result of the analysis, there was a significant difference statistically between the 6MWT distances according to children's age groups. It was identified that children aged 10-12 have had statistically better 6-MWT distance than the children aged 7-9, and children aged 13-14 have had statistically the best 6 MWT distance of all $(p=0.001)$.

\section{DISCUSSION}

As a result of this research, the 6-MWT distance/records of healthy Turkish children has/have been shown in Table 1. It was identified that the mean walking distance of the children aged $7-14$ was $684.20 \pm 109.31 \mathrm{~m}$; as the age, height and weight increased, there was also an increase in the walking distance.The six-minutes walking distance of the 10-12 years old children was higher than the79 years old, and the children aged 13-14 was higher than the other age groups. 


\begin{tabular}{|c|c|c|c|c|c|c|}
\hline $\begin{array}{c}\text { Age } \\
\text { (years) }\end{array}$ & $\mathrm{n}$ & $\begin{array}{l}\text { Height } \\
(\mathrm{cm})\end{array}$ & $\begin{array}{l}\text { Weight } \\
(\mathrm{kg})\end{array}$ & $\begin{array}{c}\text { 6MWT } \\
(\mathrm{m})\end{array}$ & $\begin{array}{c}\text { Total average } \\
(\mathrm{m})\end{array}$ & $\begin{array}{l}\mathrm{t} \\
\mathrm{p}\end{array}$ \\
\hline 7 & $\begin{array}{c}96 \\
\text { (Girl:44-Boy:52) }\end{array}$ & $\begin{array}{l}125.98 \pm 4.56 \\
122.98 \pm 4.69\end{array}$ & $\begin{array}{l}25.72 \pm 4.29 \\
24.59 \pm 4.69\end{array}$ & $\begin{array}{l}607.20 \pm 68.21 \\
597.81 \pm 64.72\end{array}$ & $602.11 \pm 66.15$ & $\begin{array}{c}-0,691 \\
0.805\end{array}$ \\
\hline 8 & $\begin{array}{c}64 \\
\text { (Girl:25-Boy :39) }\end{array}$ & $\begin{array}{l}126.80 \pm 3.88 \\
128.87 \pm 4.63\end{array}$ & $\begin{array}{l}25.88 \pm 3.02 \\
27.46 \pm 4.67\end{array}$ & $\begin{array}{l}635.80 \pm 59.89 \\
615.18 \pm 75.64\end{array}$ & $623.23 \pm 70.14$ & $\begin{array}{r}-1.150 \\
0.080\end{array}$ \\
\hline 9 & $\begin{array}{c}41 \\
\text { (Girl:19-Boy:22) }\end{array}$ & $\begin{array}{l}133.64 \pm 6.21 \\
132.64 \pm 5.07\end{array}$ & $\begin{array}{l}28.16 \pm 3.92 \\
31.84 \pm 5.35\end{array}$ & $\begin{array}{l}635.79 \pm 99.66 \\
649.50 \pm 75.79\end{array}$ & $643.15 \pm 86.79$ & $\begin{array}{l}0.500 \\
0.437\end{array}$ \\
\hline 10 & $\begin{array}{c}90 \\
\text { (Girl:46-Boy:44) }\end{array}$ & $\begin{array}{l}138.96 \pm 6.95 \\
138.55 \pm 7.17\end{array}$ & $\begin{array}{l}34.46 \pm 7.77 \\
36.48 \pm 8.97\end{array}$ & $\begin{array}{l}651.51 \pm 124.62 \\
624.57 \pm 110.18\end{array}$ & $638.34 \pm 117.90$ & $\begin{array}{c}-1.085 \\
0.385\end{array}$ \\
\hline 11 & $\begin{array}{c}75 \\
\text { (Girl:40-Boy:35) }\end{array}$ & $\begin{array}{c}148 \pm 6.88 \\
148.14 \pm 8.46\end{array}$ & $\begin{array}{l}41.25 \pm 8.58 \\
39.69 \pm 8.65\end{array}$ & $\begin{array}{c}687.98 \pm 50.0 \\
732.71 \pm 73.27\end{array}$ & $708.85 \pm 65.52$ & $\begin{array}{l}3.119 \\
0.241\end{array}$ \\
\hline 12 & $\begin{array}{c}173 \\
\text { (Girl:82-Boy:92) }\end{array}$ & $\begin{array}{l}150.53 \pm 8.07 \\
152.27 \pm 9.30\end{array}$ & $\begin{array}{c}42.49 \pm 11.0 \\
42.20 \pm 8.7\end{array}$ & $\begin{array}{l}699.48 \pm 105.42 \\
744.68 \pm 101.03\end{array}$ & $724.21 \pm 105.02$ & $\begin{array}{l}2.786 \\
0.905\end{array}$ \\
\hline 13 & $\begin{array}{c}105 \\
\text { (Girl:45-Boy:60) }\end{array}$ & $\begin{array}{l}157.96 \pm 7.26 \\
158.50 \pm 8.85\end{array}$ & $\begin{array}{l}50.64 \pm 11.7 \\
47.81 \pm 9.94\end{array}$ & $\begin{array}{l}721.96 \pm 130.75 \\
764.53 \pm 106.45\end{array}$ & $746.28 \pm 118.78$ & $\begin{array}{l}1.838 \\
0.379\end{array}$ \\
\hline 14 & $\begin{array}{c}88 \\
\text { (Girl:42-Boy:46) }\end{array}$ & $\begin{array}{l}160.57 \pm 6.05 \\
166.11 \pm 8.62\end{array}$ & $\begin{array}{c}52.13 \pm 8.1 \\
54.09 \pm 10.0\end{array}$ & $\begin{array}{c}689.72 \pm 82.55 \\
729.25 \pm 109.96\end{array}$ & $710.38 \pm 99.3$ & $\begin{array}{l}1.893 \\
0.803\end{array}$ \\
\hline Total & 732 & $145.1 \pm 15.1$ & $39.2 \pm 12.5$ & $684.20 \pm 109.31$ & $684.20 \pm 109.31$ & \\
\hline
\end{tabular}

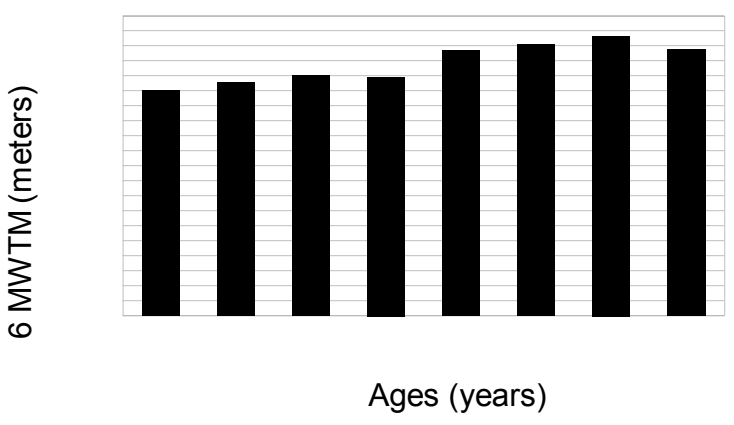

Figure 1. 6 MWT distance record for all age groups.

The 6-MWT evaluates the durability and the ability to walk a long distance (2). As a first result, the mean walking distance for children aged 7-14 was $684 \pm 109.31 \mathrm{~m}$. When the Turkish children's durability and their ability to walk long distance or their functional capacities have been examined by considering the results of other studies, it was determined that the mean walking distance of the children aged 4-11 was $470 \pm 59 \mathrm{~m}$ (14), whereas the mean walking distance of the American children aged 7-11 was $518.50 \pm 73.56 \mathrm{~m}$ (13), the mean walking distance of the Brazilian boys aged 6-12 was $579.4 \pm 68.1(20)$, and the mean walking distance of the Indian children aged 7-12 was $608 \pm 166 \mathrm{~m}$ (6). The variety of the age groups and the numbers of girls and boys in the sample group limit an exact comparision when the Turkish children in this study and the others were compared. However, the data obtained from the original researches were presented in Table 2 for an approximate benchmarking. Secondly, it was determined that there was a positive correlation between walking distance and age, height and weight; besides that the walking distance increases with the rising of weight and height. It was also determined that the walking distance increased with the rising of age, but at the age of 14 there was a fall. However, this decrease was not significant $(\mathrm{p}<0.05)$.

Similarly, Geomans et al. (11) found out that distance has increased with age in their research for test-retest. When the results of the average walking distance was compared with the results of this study, it was found that they were lower walking distance than Turkish children. However, only the boys were evaluated in Geoman's research. It was also possible to compare Turkish children with some other countries from the comparative data in Table 2. Walking speed is related with the functional ability and balance. Yet, there are many factors that affect walking. These are the individual's health conditions, age, gender, anthropometric features, motor control, muscle performance, muscle-skeletal status, sensorial and perceptual function, durability and constant activity level, cognitive status, motivation, mental health, and environmental features (8). 
In this study, the impact of gender, age, height and weight factors were examined and a significant difference was found in walking distance between the genders (Figure II). However, it was determined in the correlation study done by Limsuwan et al.
(2010) with 9-12 aged healthy children that although the boys walked longer than girls, there was not any significant difference between them (17). Moreover the distance of 119 boys and girls aged 9-11 were similar to each other (10).

Table 2. The 6-MWT comparative data of healthy children.

\begin{tabular}{|c|c|c|c|c|c|c|c|c|}
\hline Ages (years) & 7 & 8 & 9 & 10 & 11 & 12 & 13 & 14 \\
\hline $\begin{array}{l}\text { This study } \\
\text { (2013) }\end{array}$ & $\begin{array}{c}\text { G:44 } \\
\text { B:52 } \\
607.20 \pm 68.21 \\
597.81 \pm 64.72 \\
\end{array}$ & $\begin{array}{c}\text { G:25 } \\
\text { B:39 } \\
635.80 \pm 59.89 \\
615.18 \pm 75.64 \\
\end{array}$ & $\begin{array}{c}\text { G:19 } \\
\text { B:22 } \\
635.79 \pm 99.66 \\
649.50 \pm 75.79 \\
\end{array}$ & $\begin{array}{c}\text { G: } 46 \\
\text { B: } 44 \\
651.51 \pm 124.62 \\
624.57 \pm 110.18 \\
\end{array}$ & $\begin{array}{c}\text { G: } 40 \\
\text { B: } 35 \\
687.98 \pm 50.0 \\
732.71 \pm 73.27 \\
\end{array}$ & $\begin{array}{c}\text { G:82 } \\
\text { B:92 } \\
699.48 \pm 105.42 \\
744.68 \pm 101.03 \\
\end{array}$ & $\begin{array}{c}\text { G: } 45 \\
\text { B: } 60 \\
721.96 \pm 130.75 \\
764.53 \pm 106.45 \\
\end{array}$ & $\begin{array}{c}\text { G: } 42 \\
\text { B: } 46 \\
689.72 \pm 82.55 \\
729.25 \pm 109.96 \\
\end{array}$ \\
\hline Li et al. (16) & & & & $\begin{array}{c}11.9 \pm 2.6 \text { years } \\
680.9 \pm 65.3\end{array}$ & $\begin{array}{c}12.1 \pm 2.7 \text { years } \\
642.7 \pm 58.9 \\
\end{array}$ & & & \\
\hline Saad et al. (21) & $\begin{array}{c}6-7 \\
\text { G:16/B:16 } \\
616 \pm 53 / 543 \pm 33 \\
\end{array}$ & $\begin{array}{r}\mathrm{C} \\
648 \\
\end{array}$ & $\begin{array}{l}16 \\
67 \pm 55 \\
\end{array}$ & $\begin{array}{r}\text { G: } \\
693 \pm 6\end{array}$ & $\begin{array}{l}16 \\
5 \pm 31 \\
\end{array}$ & $\begin{array}{r}1 \\
\text { G: } \\
757 \pm 5\end{array}$ & 21 & $\begin{array}{c}14-15 \\
\text { G:19/B:21 } \\
718 \pm 41 / 793 \pm 84\end{array}$ \\
\hline $\begin{array}{c}\text { Priesnitz et al. } \\
\text { (17) }\end{array}$ & $\begin{array}{c}\text { B: } 92 \\
550.2 \pm 61.6\end{array}$ & $559.7 \pm 67.2$ & $594.2 \pm 60.6$ & $602.4 \pm 61.1$ & $608.0 \pm 54.3$ & $618.1 \pm 51.4$ & & \\
\hline $\begin{array}{c}\text { Limsuwan et al. } \\
\text { (17) }\end{array}$ & & & & $\begin{array}{r}\text { B: } 5 \\
591.1 \pm 40 .\end{array}$ & $\begin{array}{l}47 \\
30.4 \pm 47.6 \\
\end{array}$ & & & \\
\hline $\begin{array}{l}\text { Klepper and } \\
\text { Muir (13) }\end{array}$ & $\begin{array}{r}\text { G:1 } \\
519.6 \\
534 .\end{array}$ & & $\begin{array}{c}\text { G:16/B:11 } \\
542.54 \pm 80.25 \\
515.83 \pm 81.4 \\
\end{array}$ & $\begin{array}{c}\text { G:22/B:13 } \\
496.69 \pm 63.98 \\
497.94 \pm 4.03\end{array}$ & $\begin{array}{c}\text { G:4/B:4 } \\
532.33 \pm 92.25 \\
534.93 \pm 88.90 \\
\end{array}$ & & & \\
\hline Gatica et al. (9) & $\begin{array}{c}\text { G:9/B:7 } \\
568.2 \pm 31.6 \\
597.11 \pm 33.6 \\
\end{array}$ & $\begin{array}{c}\text { G:12/B:11 } \\
556.5 \pm 48.9 \\
605.8 \pm 62.2 \\
\end{array}$ & $\begin{array}{c}\mathrm{G}: 12 / \mathrm{B}: 6 \\
575.7 \pm 53.2 \\
611.4 \pm 47 \\
\end{array}$ & $\begin{array}{c}\text { G:10/B:12 } \\
585.7 \pm 28.7 \\
618.7 \pm 67.5 \\
\end{array}$ & $\begin{array}{c}\text { G:8/B:9 } \\
606.7 \pm 60.3 \\
608.7 \pm 35.9 \\
\end{array}$ & $\begin{array}{c}\text { G:12/B:14 } \\
629.4 \pm 20.3 \\
636.1 \pm 47.3 \\
\end{array}$ & $\begin{array}{c}\text { G:15/B:12 } \\
631.4 \pm 50.2 \\
673.9 \pm 45 \\
\end{array}$ & $\begin{array}{c}\text { G:11/B:12 } \\
638.5 \pm 20.9674 .3 \\
\pm 54.2\end{array}$ \\
\hline D'Silva et al. (6) & $\begin{array}{c}\text { G:32/B:33 } \\
\text { Minimum } \\
300 \\
\text { Maximum } 1101\end{array}$ & $\begin{array}{c}\text { G:32/B:34 } \\
\text { Minimum } \\
210 \\
\text { Maximum } \\
800 \\
\end{array}$ & $\begin{array}{c}\text { G:34/B:34 } \\
\text { Minimum } \\
225 \\
\text { Maximum } \\
945 \\
\end{array}$ & $\begin{array}{c}\text { G:34/B:34 } \\
\text { Minimum } \\
240 \\
\text { Maximum } \\
1010 \\
\end{array}$ & $\begin{array}{c}\text { G:33/B:34 } \\
\text { Minimum } \\
200 \\
\text { Maximum } \\
1010 \\
\end{array}$ & $\begin{array}{c}\text { G:33/B:33 } \\
\text { Minimum } \\
240 \\
\text { Maximum } \\
1010 \\
\end{array}$ & & \\
\hline $\begin{array}{l}\text { Pathare et al. } \\
\text { (19) }\end{array}$ & $\begin{array}{c}7.2 \pm 1.2 \text { years } \\
\text { G: } 26 \\
\text { B: } 15 \\
5254 \pm 58.1 \\
\end{array}$ & & & & & & & \\
\hline $\begin{array}{c}\text { Geomans et al. } \\
\text { (11) }\end{array}$ & 547 & & 57 & & & & & \\
\hline
\end{tabular}

As shown in Table 2, when ages compared, it was observed that the walking distance of the 9 years-old boys, was higher than that of the 9 yearold girls.

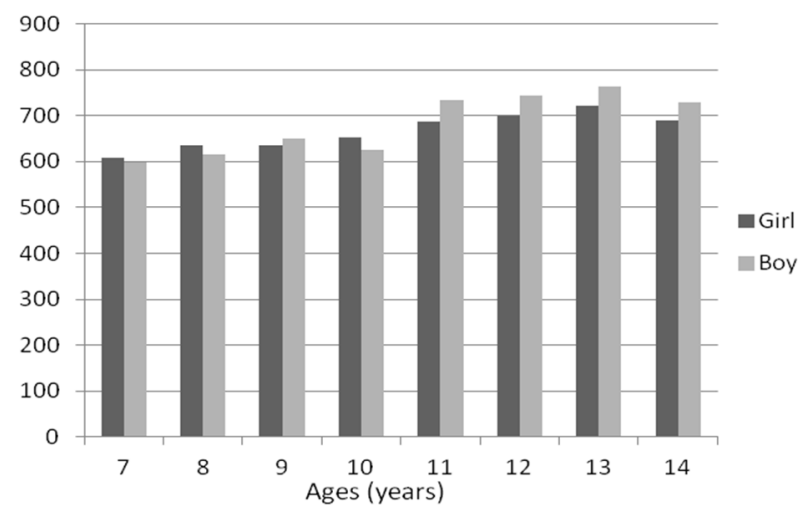

Figure 2. 6 MWT for girls and boys

When the results of the study by Gatica et al. (9) have been compared with this study, it was observed that walking distance of the 7-years-old Turkish girls were higher than that of the Chilean girls at the same age, the boys were similar, and the walking distance of the Turkish children aged 814 ,was higher than that of the Chilean children.

The $663 \mathrm{~m}$ walking distance of 97 healthy children aged 8-16 in the 6 MWT validity and reliability studies of obese children and adolescents by Morinder et al. (18) was lower than that of the Turkish children. Yet, the number of children in two groups was different. Looking at the data from other countries, it was identified that the $6 \mathrm{MWT}$ mean of Indian children aged 7-12 was $609 \pm 166 \mathrm{~m}$, there was a significant difference between girls and boys; boys' walking distance was higher than girls, and the 6MWT walking distance increased with age (6).

Compared with the results of this research includin children aged 7-14, the average walking distance of Turkish children was higher. However, it should not be overlooked that the absence of two age groups of Indian children can change the results. When it was compared with the American girls aged 9-11, it was identified that the Turkish children's 
walking distance was higher than that of the American girls (13).

\section{REFERENCES}

1. ATS Statement: Guidelines for the six-minute walk test. ATS Committee on proficiency standards for clinical pulmonary function laboratories. Am J Respir Crit Care Med, 2002; 166(1):111-7.

2. Bennell K, Dobson F, Hinman R. Measures of physical performance assessments. Arthritis Care \& Research, 2011; 63(Supl 11): 350-370.

3. Clarke LA, Wraith JE, Beck M, Kolodny EH, Pastores GM, Muenzer J, Rapoport DM, Berger KI, Sidman M. Long-term Efficacy and Safety of Laronidase in the Treatment of Mucopolysaccharidosis I. Pediatrics, 2009; 123(1): 229 -240.

4. Cote CG, Casanova C, Mari'n JM, Lopez MV, Pinto-Plata V, de Oca MM, Dordelly LJ, Nekach H, Celli BR. Validation and comparison of reference equations for the 6-min walk distance test. Eur Respir J, 2008; 31: 571-578.

5. Cunha MT, Rozov T, Caitano de Oliveira R, Jardim JR. Sixminute walk test in children and adolescents with cystic fibrosis. Pediatr Pulmonol, 2006; 41: 618-622.

6. D'silva C, Vaishali K, Venkatesan P. Six-Minute Walk Testnormal values of school children aged 7-12 Y in India: A cross-sectional study, Indian J Pediatr, 2012; 79(5):597-601.

7. Enright PL. The six-minute walk test. Respir Care, 2003; 48: 783-785.

8. Fritz S, Lusardi M. White paper: walking speed: the sixth vital sign. Journal Geriatrics Physical Therapy, 2009; 32(2):2-5.

9. Gatica D, Puppo H, Villarroel G, San Martín I, Lagos $\mathrm{R}$, Montecino JJ, Lara C, Zenteno D. Reference values for the 6-minutes walking test in healthy Chilean children. Rev Med Chile, 2012; 140: 1014-1021.

10. Geiger R, Strasak A, Treml B, Gasser K, Kleinsasser A, Fischer V, Geiger H, Loeckinger A, Stein JI. Six-minute walk test in children and adolescents. J Pediatr, 2007; 150: 395-9.

11. Goemans N, Klingels K, Van den Hauwe M, Van Orshoven A, Vanpraet S, Feys H, Buyse G. Test-retest reliability and developmental evolution of the 6-min walk test in Caucasian boys aged 5-12 years. Neuromuscul Disord, 2013; 23(1):19-24.

12. Hassan J, Van der Net J, Helders PJM, Prakken BJ, Takken T. Six-minute walk test in children with chronic conditions, $\mathrm{Br} J$ Sports Med, 2010; 44: 270-274.

13. Klepper SE Muir N. Reference values on the 6 -minute walk test for children living in the United states. Pediatr Phys Ther, 2011; 23: 32-40.

14. Lammers AE, Hislop AA, Flynn Y, Haworth SG. The 6 minute walk Test: normal values for children of 4-11 years of age. Arch Dis Child, 2008; 93(6): 464-468.

15. Li AM, Yin J, Yu CC, Tsang T, So HK, Wong E, Chan D, Hon EK, Sung R. The six-minute walk test in healthy children: reliability and validity. Eur Respir J, 2005; 25:1057-1060.

16. Li AM, Yin J, Au JT, So HK, Tsang T, Wong E, Fok TF, Ng PC. Standard Reference for the Six-Minute-Walk Test in Healthy Children Aged 7 to 16 Years. American Journal of Respiratory and Critical Care Medicine, 2007; 176(2): 174-180.
17. Limsuwan A, Wongwandee $R$, Khowsathit P. Correlation between 6-min walk test and exercise stress test in healthy children. Acta Paediatrica, 2010; 99(3): 438-441.

18. Morinder G, Mattsson E, Sollander C, Marcus C, Larsson UE. Six-minute walk test in obese children and adolescents: reproducibility and validity. Physiotherapy Research International, 2009; 14(2): 91-104.

19. Pathare N, Haskvitz EM, Selleck M. 6-Minute Walk Test performance in young children who are normal weight and overweight. Cardiopulm Phys Ther J, 2012; 23(4): 12-18.

20. Priesnitz CV, Rodrigues GH, Stumpf CS, Viapiana G, Cabral $\mathrm{CP}$, Stein RT, Marostica PJ, Donadio MV. Reference values for the 6-min walk test in healthy children aged 6-12 years. Pediatric Pulmonology, 2009; 44(12): 1174-1179.

21. Saad HB, Prefaut C, Missaoui R, Mohamed IH, Tabka Z, Hayot M. Reference equation for 6-min walk distance in healthy North African children 6-16 years old. Pediatric Pulmonology, 2009; 44:316-324. 